\title{
Endocrine factors modulating immune responses in pregnancy
}

\author{
Anne Schumacher ${ }^{1}$, Serban-Dan Costa ${ }^{2}$ and Ana Claudia Zenclussen ${ }^{1}$ \\ ${ }^{1}$ Department of Experimental Obstetrics and Gynecology, Medical Faculty, Otto-von-Guericke University, Magdeburg, Germany \\ 2 University Women's Clinic, Otto-von-Guericke University, Magdeburg, Germany
}

\section{Edited by:}

Sinuhe Hahn, University Clinics Basel,

Switzerland

\section{Reviewed by:}

Fulvio D'Acquisto, Queen Mary University of London, UK

Stavros Giaglis, University of Basel,

Switzerland

Ralph Kay Heinrich Nanan, The

University of Sydney, Australia

\section{${ }^{*}$ Correspondence:}

Anne Schumacher, Department of

Experimental Obstetrics and Gynecology, Medical Faculty,

Otto-von-Guericke University, Gerhart-Hauptmann Straße 35,

Magdeburg 39108, Germany

e-mail: anne.schumacher@

med.ovgu.de
How the semi-allogeneic fetus is tolerated by the maternal immune system remains a fascinating phenomenon. Despite extensive research activity in this field, the mechanisms underlying fetal tolerance are still not well understood. However, there are growing evidences that immune-immune interactions as well as immune-endocrine interactions build up a complex network of immune regulation that ensures fetal survival within the maternal uterus. In the present review, we aim to summarize emerging research data from our and other laboratories on immune modulating properties of pregnancy hormones with a special focus on progesterone, estradiol, and human chorionic gonadotropin. These pregnancy hormones are critically involved in the successful establishment, maintenance, and termination of pregnancy. They suppress detrimental maternal alloresponses while promoting tolerance pathways. This includes the reduction of the antigen-presenting capacity of dendritic cells (DCs), monocytes, and macrophages as well as the blockage of natural killer cells, T and B cells. Pregnancy hormones also support the proliferation of pregnancy supporting uterine killer cells, retain tolerogenic DCs, and efficiently induce regulatory $T$ (Treg) cells. Furthermore, they are involved in the recruitment of mast cells and Treg cells into the fetal-maternal interface contributing to a local accumulation of pregnancy-protective cells. These findings highlight the importance of endocrine factors for the tolerance induction during pregnancy and encourage further research in the field.

Keywords: progesterone, estradiol, human chorionic gonadotropin, luteinizing hormone, alpha-fetoprotein, immune regulation, pregnancy

\section{INTRODUCTION}

It is said that mammalian pregnancy defies the immunological rules because a semi-allogeneic conceptus is tolerated rather than rejected. It is therefore, a fascinating phenomenon and target of many immunological studies. Pregnancy is however a natural phenomenon that ensures the survival of species and exists since millions of years. By contrast transplantation, where empirical observations led to the definition of the immunological rules, is an artificial process that was first described in 1905. Thus, understanding how natural tolerance operates may help creating novel strategies to ensure tolerance in other models. Especially because of the fact that initial allorecognition of foreign fetal antigens by the maternal immune system is advantageous for a successful pregnancy, the mechanisms behind gestational tolerance are of interest for other disciplines. Local suppression of alloreactive immune responses to paternal antigens is a prerequisite for fetal acceptance. Steroid hormones like progesterone (P4) and estradiol (E2) as well as gonadotropins such as the human chorionic gonadotropin (hCG) are fundamentally involved in the regulation of the menstrual cycle and in the establishment and maintenance of pregnancy $(1,2)$. Through binding their specific receptors expressed by immune cells and/or by acting via mediators these hormones support fetal tolerance by inhibiting destructive immune responses and inducing tolerance pathways.
This review highlights the effects of pregnancy-associated hormones on different immune cell types with a special focus on P4, E2, and hCG.

\section{PROGESTERONE}

P4 is a member of the steroid hormone family and has been described as the "pregnancy hormone" due to its indispensable role for pregnancy maintenance (3). During the menstrual cycle, P4 levels are relatively low during the preovulatory phase, rise after ovulation, and are elevated during the luteal phase (4). If pregnancy occurs, hCG initially maintains $\mathrm{P} 4$ levels by inducing its production by the corpus luteum. After the luteal-placental shift, the placenta takes over P4 production (5). P4 prepares the uterus for implantation as it induces differentiation of stromal cells into decidual cells (decidualization) and decreases the contractility of uterine smooth muscle cells $(6,7)$. Additionally, P4 withdrawal is associated with the initiation of labor (8). P4 has been shown to affect immunity, mainly at pregnancy concentrations. These effects are primarily mediated via the intracellular P4 receptors (PR), PR-A and PR-B, which act as transcription factors, although non-genomic effects of PR activation have been reported (9). In addition, P4 mediates its immune regulatory function via mediators such as the progesterone-induced blocking factor (PIBF) and glycodelin A $(10,11)$. 


\section{ESTRADIOL}

Like progesterone, estrogens belong to the steroid hormones. Three major naturally occurring estrogens have been described in women, namely estrone (E1), estradiol (E2), and estriol (E3). Within those, E2 is the predominant estrogen produced during the reproductive years. High levels of E2 are produced by the ovary, while smaller amounts are also produced by the adrenal cortex and from E2 precursors in fatty tissues (12). In the normal menstrual cycle, E2 levels rise with follicular development, drop briefly at ovulation, and rise again during the luteal phase for a second peak. At the end of the luteal phase, E2 levels drop to their menstrual levels unless there is a pregnancy (13). During pregnancy, E2 levels increase continuously until term due to the production by the growing placenta (14). Several important functions have been described for E2. During the menstrual cycle, E2 triggers the luteinizing hormone (LH) surge resulting in ovulation. After ovulation, in the luteal phase, E2, in conjunction with $\mathrm{P} 4$ prepares the endometrium for implantation. Upon pregnancy, E2 is shown to promote uterine blood flow, myometrial growth, stimulate breast growth and at term, promote cervical softening and expression of myometrial receptors. Besides, E2 was suggested to affect different immune cell populations in their number and function and thereby contributes to fetal tolerance. These effects are mediated via binding of E2 to its intracellular receptors, estrogen receptor alpha $(\mathrm{ER} \alpha)$ and beta $(\mathrm{ER} \beta)$, which in turn modulate the expression of many genes (15). Both receptors are expressed in various lymphoid tissue cells as well as in lymphocytes, macrophages, and dendritic cells (DCs) $(16,17)$.

\section{HUMAN CHORIONIC GONADOTROPIN}

Human chorionic gonadotropin is a primate-specific heterodimeric placental glycoprotein. Four different hCG variants, namely total hCG, hyperglycosylated hCG (hCG-H), free $\beta$ subunit, and pituitary hCG, have been reported, each produced by different cells with separate biological functions (18). In humans, after pregnancy onset, total hCG increases rapidly during the first trimester, peaks between the 9th and 12th week of pregnancy and then declines, until the woman gives birth, although remaining higher than in a non-pregnant woman (19). hCG is produced by differentiated syncytiotrophoblasts and its main function is to stimulate $\mathrm{P} 4$ production by the corpus luteum (20). Moreover, hCG supports pregnancy by facilitating trophoblast invasion (21-23), promoting angiogenesis, and ensuring nourishment of the fetus (24-26). In rodents, similar functions are mediated by the highly homologous LH. During the last years, there is growing evidence that hCG and $\mathrm{LH}$ are involved in immune tolerance mechanisms leading to fetal survival. Both gonadotropins were shown to affect immune cells by binding to the LH/CG receptor expressed by several immune cell types. Moreover, hCG also acts through the mannose receptor.

\section{ALPHA-FETOPROTEIN}

Alpha-fetoprotein (AFP) is a glycoprotein that is produced by the yolk sac and fetal liver during pregnancy (27). It is the most abundant plasma protein found in the human fetus, acting as a fetal transport protein. AFP levels increase in the 4-week-old fetus, peak between the 12th and 16th week and remain low after birth. Although several studies provide evidence for an immune regulatory potential of AFP (28-32), it is still not explored whether AFP contributes to pregnancy success by modulating immune responses.

\section{HORMONAL INFLUENCE ON IMMUNE CELLS DURING PREGNANCY \\ EFFECT OF PREGNANCY HORMONES ON MACROPHAGES}

Monocytes and macrophages are major representatives of the innate immune system in the cycling and pregnant mammalian uterus. Several studies provide evidence that monocyte recruitment, differentiation into macrophages, and function in the reproductive tract is modulated by pregnancy-associated hormones (33). Hormonal influence may be achieved by directly binding to the appropriate hormone receptors expressed on human and murine macrophages $(16,34,35)$ or indirectly by modulating the levels of cytokines and growth factors that target the resident macrophages and influence their secretory profile. Hunt and colleagues reported that $\mathrm{P} 4$ reduced macrophage migration into the murine uterus (36), while Kitzmiller and colleagues showed that E2, P4, and hCG did not affect macrophage migration in guinea pigs (37). Differentiation of monocytes into macrophages was hindered by glycodelin A, a P4 mediator, by induction of apoptosis in human monocytes. However, after differentiation glycodelin A was not able to alter phagocytic capacity of macrophages (11). Macrophages are important regulators of trophoblast activity that promote tissue remodeling and angiogenesis (38). In this regard, E2, hCG, and LH have been demonstrated to enhance the production of the vascular endothelial growth factor (VEGF) in human macrophages $(39,40)$, supporting vessel formation in the placenta. In addition, P4 impairs the ability of human and murine macrophages to produce potent effector molecules such as nitric oxide and IL-1 proven to be detrimental for successful pregnancy outcome $(36,41,42)$. Moreover, P4 suppresses toll-like receptor-triggered activation of murine macrophages by regulating miR-155 expression (43). Menzies and colleagues recently suggested an involvement of $\mathrm{P} 4$ in the regulation of genes associated with alternative macrophage activation (44). By contrast, hCG treatment of human and murine IFN- $\gamma$-primed macrophages resulted in increased production of nitric oxide, reactive oxygen species, IL-6 and IL-12p40, and enhanced phagocytosis of apoptotic cells $(45,46)$. However, hCG treatment of murine IFN$\gamma$-primed macrophages did not affect the induction of allogeneic $\mathrm{T}$ cell proliferation (45). Interestingly, macrophages regulate excess of hCG known to be teratogenic to fetal tissues. Here, human macrophages are proposed to incorporate and degrade hCG in a time-dependent manner that protect fetal gonadogenesis from excess hCG $(47,48)$. More precisely, Katabuchi and colleagues recently demonstrated that hCG induces transient vacuole formation in human monocytes, morphologically mimicking Hofbauer cells. The authors suggest that Hofbauer cells and especially their vacuoles are involved in the protection of fetal tissue from high amounts of maternal hCG (49). Besides an effect of steroid hormones and gonadotropins on monocytes and macrophages, AFP is suggested to have an influence on both innate immune cell 


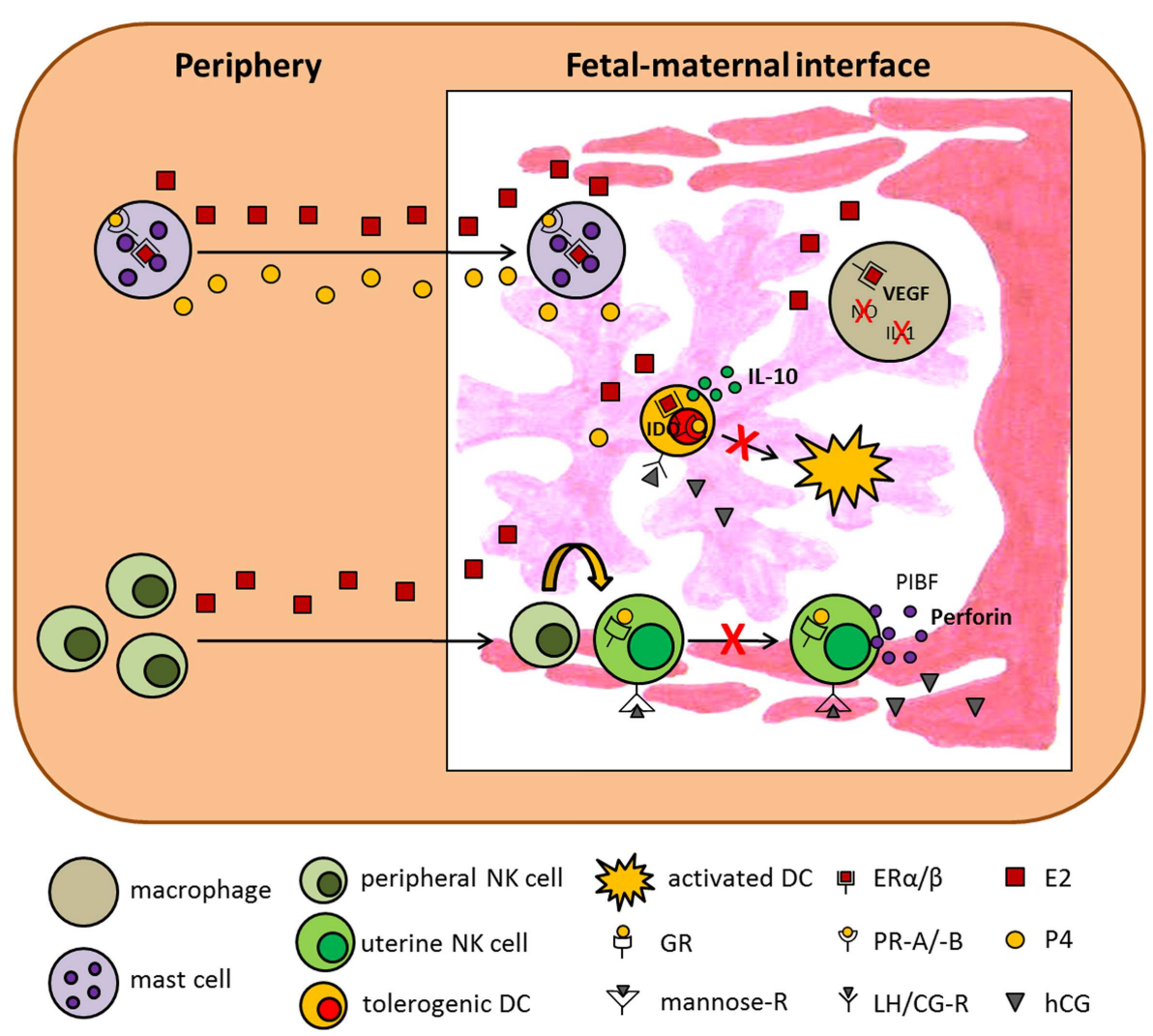

FIGURE 1 | Hypothetical scenario presenting the influence of pregnancy-associated hormones on innate immunity. The scenario suggests several mechanisms by which E2, P4, and hCG influence innate immune cells and thereby support pregnancy success. ER, estrogen receptor;
GR, glucocorticoid receptor; IDO, indoleamine 2,3-dioxygenase; IL-1, interleukin-1; IL-10, interleukin-10; LH/CG-R, luteinizing hormone/chorionic gonadotropin receptor; NO, nitric oxide; PIBF, progesterone-induced blocking factor; PR, progesterone receptor; VEGF, vascular endothelial growth factor. types. It has been demonstrated that AFP significantly suppresses the production of TNF $\alpha$ and IL- $1 \beta$ and induces a rapid downregulation of surface $\mathrm{MHC}$ class II expression in a stimulated human monocyte cell line $(29,31)$. Moreover, $\mathrm{Lu}$ and colleagues showed that AFP inhibits the cell surface expression of Ia antigens on macrophages but does not affect macrophage viability (50). Hormonal effects on macrophages are summarized in Figure 1.

\section{EFFECT OF PREGNANCY HORMONES ON NATURAL KILLER CELLS}

NK cells and, in particular, uterine NK (uNK) cells are of special interest when analyzing mechanisms underlying normal pregnancy. This becomes obvious when taking into account that uNK cells are the predominant lymphocyte population in the late secretory phase of the menstrual cycle and in the early pregnant uterus representing circa $70 \%$ of all leukocytes in decidual tissue. uNK cells differ from peripheral NK cells in the expression of their receptor repertoire and in the expression of some genes induced by the hormonal environment. The main function of uNK cells is to regulate maternal uterine vasculature remodeling (51). Therefore, it has been demonstrated in the murine system that uNK cells produce proangiogenic factors such as VEGF and growth factors and provide local IFN- $\gamma$ for initiation of spiral artery formation (52-54). Their origin or expansion remains a matter of discussion. They may migrate from the periphery, differentiating from $\mathrm{NK}$ cell progenitors under the control of different factors, including steroid hormones (55), and/or by recruitment of peripheral NK cells into the uterus (56-58) or expand in situ after pregnancy was established (59). Qu and colleagues demonstrated a P4-dependent osteopontin expression in human decidual stroma cells and human uNK cells and proposed a role for osteopontin in uNK cell accumulation in uterine tissue (60). Moreover, human uNK cell recruitment from the peripheral blood into the uterus seems to be favored by rising E2 and LH levels and restricted by increasing amounts of P4 (61). Interestingly, mature human and rodent uNK cells do not express steroid receptors $(55,62-64)$. Thus, it is suggested that, at least for $\mathrm{P} 4$, effects are mediated through the glucocorticoid receptor (GR), proven to be expressed on murine $\mathrm{uNK}$ cells (65). In addition to the lack of steroid receptors, uNKs also miss the classical LH/CG receptor. Thus, hCG was suggested to induce human uNK cell proliferation through the mannose receptor (66). Regarding the function of uNK cells, they have been shown to contain high amounts of perforin but only display low cytotoxic activity. Several studies indicated that $\mathrm{P} 4$ and its mediator PIBF inhibit human NK cell activity via a block of degranulation (67-70). In agreement, E2 increased human and murine NK cell number but reduced their cytotoxicity (71, 


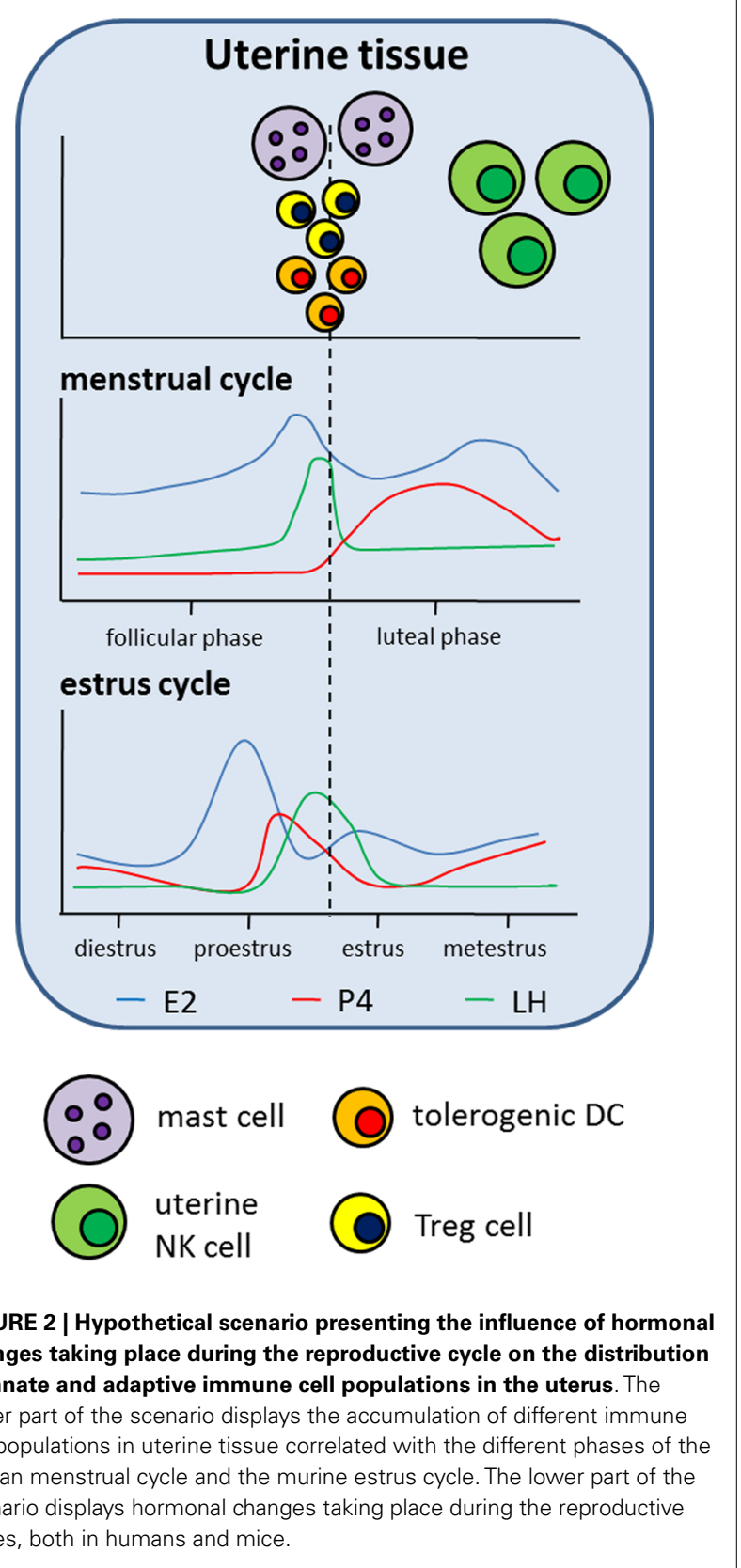

72). By contrast Kitaya and colleagues as well as Kurashige and colleagues revealed that neither P4 nor E2 had significant effects on the proliferation, cytolytic activity, and cytokine secretion of human endometrial NK cells $(73,74)$. This was also true for AFP (73). In contrast to these results, it was shown that hCG and LH applied to virgin mice resulted in an enhanced NK cell activity $(75,76)$ suggesting that pregnancy hormones differently regulate NK cell function. Moreover, contradictory results between humans and mice regarding an influence of pregnancy hormones on different immune cell populations depict the limitations of animal models in understanding mechanisms unique to human pregnancy. Finally, hCG not only influences $\mathrm{NK}$ cells but is also produced and secreted by them during pregnancy (77). Hormonal effects on NK cells are summarized in Figures 1 and 2.

\section{EFFECT OF PREGNANCY HORMONES ON MAST CELLS}

Mast cells (MCs) are best known for their effector function in allergic diseases. After binding of allergen-specific IgE to its receptor (Fc\&RI), preformed and newly synthesized mediators stored within the MCs are released to induce inflammatory immune responses (78). Beside this well-documented function of MCs, recent data suggest MCs as critical regulators of adaptive immune responses (79). Additionally, we recently uncovered a critical role for MCs in pregnancy success. To study the importance of MCs in murine pregnancy, we took advantage of a MC-deficient mouse model. We found uterine MCs (uMCs) to have a unique phenotype. uMCs increase in number every time a female becomes receptive and rapidly expand after pregnancy occurs. In the absence of MCs implantation is severely impaired and spiral artery remodeling has shown to be insufficient. This is suggested to result in fetuses that are growth-retarded (80). We also proposed a role for uMCs in trophoblast survival, placentation, and fetal growth. MC salutary role in murine pregnancy is mediated at least in part by Galectin-1 (80). Oscillations in the number of uMCs during the reproductive cycle in humans (81) and mice (82) seem to be, at least partially, hormone regulated. Several studies demonstrated that P4 and E2 influence rat and mouse MC density in different tissues, including mammary glands and uterine tissue (82-85). We additionally suggested a function for both hormones in the recruitment of murine MCs from the periphery into the uterus as well as an impact on $\mathrm{MC}$ activity (86). In agreement, several studies confirmed a major effect of P4 and E2 on rat, mouse, and human MC activation (83, $87-90)$. By contrast, two other studies did not observe alterations in the number of granulated or degranulated rat and mouse MCs after P4 or E2 treatment $(91,92)$. Hunt and colleagues revealed that E2 influences the expression of iNOS and TNF- $\alpha$ in murine uMC (93). It can be assumed that the observed effects of P4 and E2 on MCs are in part of direct nature as MCs from different species have been proven to express P4 and E2 receptors $(85-87,89,94)$. Studies analyzing the impact of hCG on MCs are rare to find in the literature. One study investigated the histamine content in MCs in a model of ovarian hyperstimulation induced in rabbits. However, hCG application seemed not to change the histamine content in MCs (95). Hormonal effects on MCs are summarized in Figures 1 and 2 .

\section{EFFECT OF PREGNANCY HORMONES ON DENDRITIC CELLS}

As professional antigen-presenting cells, DCs are at the interphase between the innate and the adaptive immune system; hence their activation and modulation is critical for the outcome of the immune response. Dependent on their activation status, DCs either secrete pro- or anti-inflammatory cytokines, thereby inducing immune responses or suppressing them, respectively. During normal pregnancy, the majority of human and murine decidual DCs presents an immature (tolerogenic) phenotype and mainly produce IL-10, thus contributing to a fetus-friendly local environment $(96,97)$. In line with this, spontaneous abortions in humans and mice are associated with an increased number of mature, IL-12-producing DCs $(98,99)$. Moreover, the importance 
of DCs for a proper decidualization and implantation has been nicely shown by Plaks and colleagues in a mouse model (100). Data regarding the influence of pregnancy-associated hormones on DC function are widespread and inconsistent. DCs derived from bone-marrow precursors or monocytes as well as DCs from spleen or decidua have been shown to react differentially to hormonal stimulation. This may offer a possible explanation how the endocrine system supports the pregnant immune system in tolerating the semi-allogeneic fetus while at the same time being aware of pathogens; these cells being pleiotropic and it should not come as a surprise that they have the machinery to respond differently depending on the situation. DCs are highly susceptible to hormonal stimulation by expressing receptors for P4, E2, hCG, and LH (101-103). Hormonal stimulation of activated bone-marrow derived DCs (BMDCs) resulted in the majority of studies in an impaired up-regulation of MHCII molecules and co-stimulatory molecules associated with a reduced capability to secrete pro-inflammatory cytokines $(101,104)$. This would imply that upon hormonal stimulation they acquire a rather pregnancy-friendly phenotype. The concrete impact of P4 on IL-10 secretion by activated rat and mouse BMDCs was differentially discussed and has to be further evaluated (101, 104, 105). In line with the hormonal-mediated induction of a tolerogenic phenotype in activated BMDCs, their T-cell stimulatory capacity was reduced. This suggests that hormone-treated DCs have a pregnancy-protective effect by suppressing alloreactive $\mathrm{T}$ cell responses $(101,104,105)$. However, results obtained after the addition of P4, E2, and hCG to monocyte-derived DCs (moDCs) from human peripheral blood are different from the results obtained after hormonal stimulation of BMDCs. Here, two studies showed that combinations of P4, E2, and hCG did not change the expression of maturation markers of moDCs or their T cell stimulatory capacity $(106,107)$. Segerer and colleagues demonstrated, at least for hCG, a pregnancy-positive effect on HLA-DR expression associated with a significant reduction in the ability to stimulate $\mathrm{T}$ cells (108). Of great interest is the fact that most of the published studies observed a significant upregulation of IL-10 production by human DCs after treatment with pregnancy hormones $(106,107,109)$. Uemura and colleagues additionally proposed an induction of $\mathrm{T}$ cell differentiation into Th2 (107), a phenotype that is reportedly pregnancy-friendly. Analysis of hormonal effects on splenic DCs has been performed in several mouse models, including models of autoimmune diseases and pregnancy. In a murine model for multiple sclerosis, namely experimental autoimmune encephalomyelitis (EAE), E2 treatment has shown to be protective. Here, E2 did not affect the expression of activation markers and co-stimulatory molecules of DCs but inhibit their ability to stimulate $\mathrm{T}$ cell proliferation and secretion of Th1 and Th2 cytokines. The reduced T cell stimulatory capacity was suggested to be due to an increased expression of indoleamine 2,3-dioxygenase (IDO) in DCs after E2 treatment $(110,111)$. Accordingly, hCG was also proven to up-regulate IDO in DCs in a murine model of autoimmune diabetes (112). As for E2, it was reported that P4 seems to affect the ratio of Th1-promoting DEC-205+ DCs and Th2-promoting $33 \mathrm{D} 1^{+}$DCs during pregnancy, favoring the dominance of $33 \mathrm{D} 1^{+}$ DCs. The need of $33 \mathrm{D} 1^{+}$DCs for pregnancy success results from the observation that depletion of this specific DC subset during the perinatal period in mice caused substantial fetal loss probably mediated through Th1 up-regulation via transient IL12 secretion (113). We have recently investigated the influence of hCG and LH on the number and phenotype of peripheral and local DCs in a murine model of disturbed tolerance to the semi-allogeneic fetus. We found that the in vivo application of both hormones prevented fetal rejection and this was associated with a reduced number of total and mature DCs both in the periphery and in decidua. Furthermore, we proved that hCG-treated decidual DCs had an elevated capacity to induce regulatory $\mathrm{T}$ (Treg) cells (103). This confirms the pregnancyprotective impact of both gonadotropins via modulation of adaptive immune responses. Effects of AFP on different DC subsets during pregnancy are almost unknown. Evidence for an AFPmediated induction of tolerogenic DCs came from a tumor model where AFP has been demonstrated to induce tolerogenic DC capable of suppressing tumor-specific $\mathrm{CD}^{+}$cytotoxic $\mathrm{T}$ lymphocytes within the tumor (114). Hormonal effects on DCs are summarized in Figures 1 and 2.

\section{EFFECT OF PREGNANCY HORMONES ON B CELLS}

$B$ lymphocytes are allocated to the adaptive immune system and they are best known for their capability to secrete antibodies. However, B cells do more than producing antibodies. They efficiently present antigens and modulate the function of $\mathrm{T}$ cells and DCs by producing cytokines $(115,116)$. During pregnancy, various B cell subsets are proposed to differently affect pregnancy outcome [reviewed in Ref. (117)]. Basically, B cells can be divided in two main populations, namely B1 and B2 B cells. These two populations differ in their developmental origin, surface marker expression and function (118). B1 B cells are then further subdivided in B1a and B1b B cells based on the expression of the surface marker CD5 (119). Interestingly, B1a B cells produce a specific type of antibody, the so-called natural antibodies (120). Due to their poly-reactive nature, natural antibodies are suggested to induce autoreactivity and thus are involved in the onset of autoimmune diseases (121). Even during pregnancy, $\mathrm{B} 1 \mathrm{a} \mathrm{B}$ cells producing natural antibodies are proposed to have detrimental effects on pregnancy outcome. We recently showed that the number of B1a B cells significantly decrease in the third trimester of normal pregnant women while remain elevated in preeclamptic patients (122). As patients suffering from pre-eclampsia have augmented serum hCG levels compared to normal pregnant women, we assumed that hCG may be responsible for the increased B1a B cell number. This assumption is further underlined by the fact that almost all B1a B cells express the LH/CG receptor and expand in vitro upon hCG stimulation (122). It was however shown that hCG inhibited antibody formation of murine B cells $(123,124)$. However, these two mentioned studies did not focus their analysis on B1a B cells but in total B cells. It is tempting to speculate that hCG may influence cell phenotype and antibody production differently in different B cell subsets. In contrast to the detrimental effect proposed for natural antibodies on pregnancy outcome, asymmetric antibodies (AABs), due to their structural anomaly, favor pregnancy success by reducing alloreactive immune responses (125). AABs increase during 


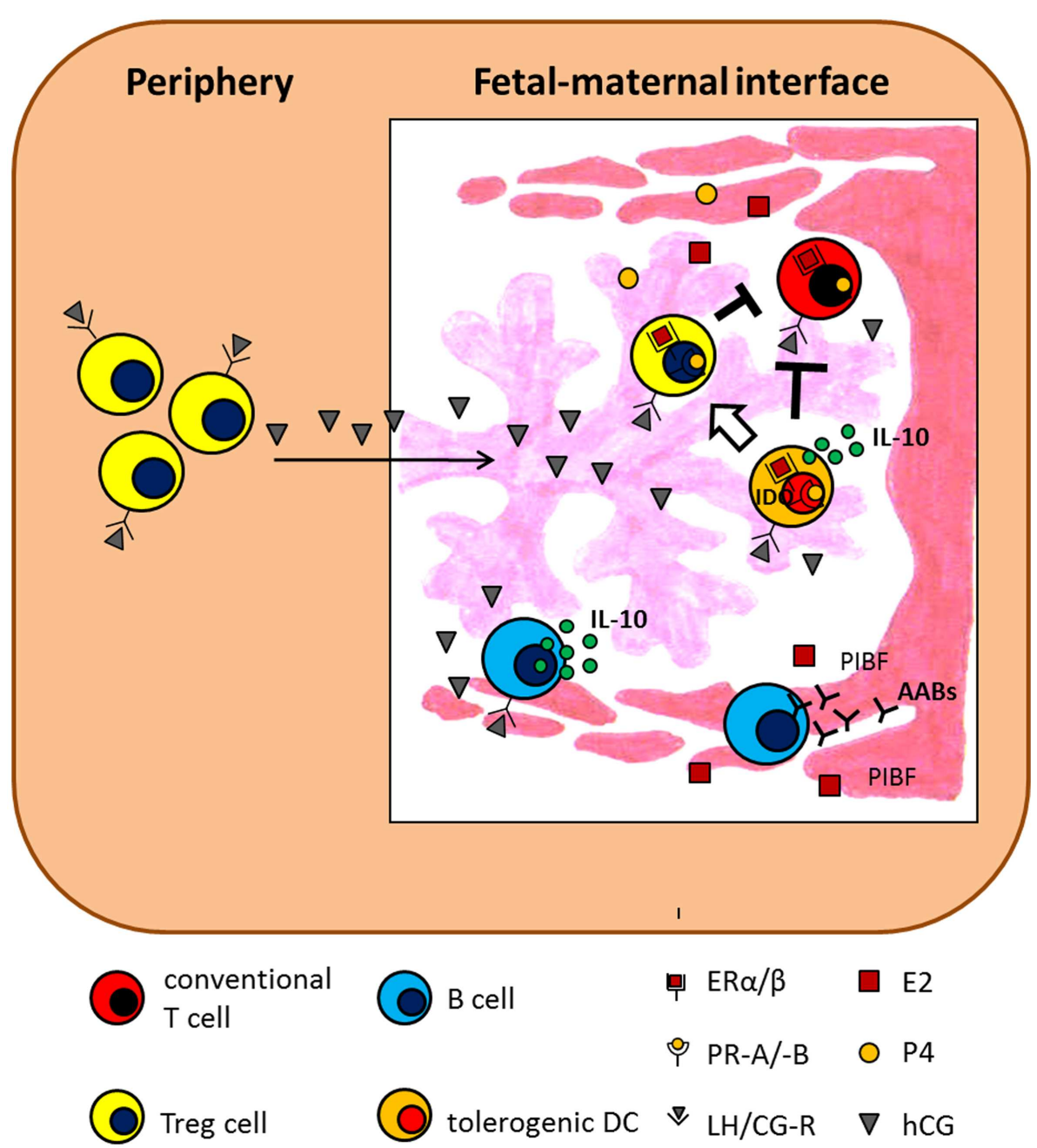

FIGURE 3 | Hypothetical scenario presenting the influence of pregnancy-associated hormones on adaptive immunity. The scenario suggests several mechanisms by which E2, P4, and hCG influence adaptive immune cells and thereby support pregnancy success. AABs, asymmetric antibodies; ER, estrogen receptor; IDO, indoleamine 2,3-dioxygenase; IL-10, interleukin-10; LH/CG-R, luteinizing hormone/chorionic gonadotropin receptor; PIBF, progesterone-induced blocking factor; PR, progesterone receptor. pregnancy and their lack is associated with pregnancy failure in humans $(126,127)$. Secretion of AABs seems to be, at least partially, hormone regulated. P4 but not E2 provoke AAB secretion (128). Hereby, P4 mediates its function via induction of PIBF (129). Beside an influence on antibody formation and secretion, pregnancy hormones also regulate $\mathrm{B}$ cell development and cytokine secretion. Administration of E2 alone, or in combination with P4, preferentially suppressed IL-7 responding cells and their progeny in bone-marrow (130). In contrast to P4 and E2, human B cell stimulation by hCG seems to be highly dependent on hCG doses and purity of hCG preparations (131-133). Recently, we proposed another pregnancy-protective effect of hCG, namely its capacity of increasing the regulatory function of human regulatory B cells (Breg or B10) shown to contribute to fetal survival. Breg express the LH/CG receptor and increase their IL-10 production in response to hCG treatment (134). Hormonal effects on B cells are summarized in Figure 3.

\section{EFFECT OF PREGNANCY HORMONES ON T CELLS}

$\mathrm{T}$ cells are key regulators of both the antibody and the cellmediated arms of the adaptive immune system and can be divided into two subcategories, CD4 expressing T helper cells and cytotoxic $\mathrm{T}$ cells expressing CD8. According to their cytokine secretion pattern, they are usually further subdivided in Th1, Th2, and Th3 cells although it is well known that this classification is oversimplified as further subsets as Th9 and Th17 has been described. T cells mediate their function either by direct cell-cell contact or indirectly by the secretion of cytokines defining the local environment as a pro-inflammatory or anti-inflammatory one. Normal pregnancy is associated with a pro-inflammatory Th1 profile at early and late pregnancy stages being important for a proper blastocyst implantation and initiation of labor, respectively. At midgestation, an anti-inflammatory Th2 profile guarantees tolerance of the foreign fetal antigens. Imbalances in cytokine profiles were associated with human pregnancy complications (135), suggesting a major 
part for $\mathrm{T}$ cells in fetal tolerance by regulating the local cytokine milieu. Steroid hormones are reportedly involved in modulating cytokine secretion by different T cell subsets. P4 and E2 are proposed to influence the Th1/Th2 balance favoring a Th2 predominance at the fetal-maternal interface in humans and mice (136-144). Hormonal effects are mainly mediated via their classical receptors expressed by human and murine T cells $(16,103,143$, $145,146)$. However, Chien and colleagues provide evidence that P4 may act through non-classical steroid receptors to cause immune modulation and suppression of $\mathrm{T}$ cell activation during pregnancy (147). In addition to regulate the cytokine secretion of T cells, steroid hormones and their mediators (e.g., glycodelin A) induce apoptosis of effector T cells (148-150) and increase the expression of pregnancy-protective molecules such as the leukemia inhibitory factor (LIF) known to modulate immune responses during early human and murine pregnancy $(151,152)$. In line with this, hCG is proposed to support fetal survival by modulating murine $\mathrm{T}$ cell activity and function $(153,154)$. More precisely, Khil and colleagues demonstrated that hCG prevented the development of the disease in a murine model of autoimmune diabetes. Here, hCG treatment efficiently suppressed IFN- $\gamma$ production, but increased IL-10 and TGF- $\beta$ production in splenocytes. hCG application also suppressed TNF- $\alpha$ production (155). In contrast, AFP apparently has no direct effect on T lymphocytes. T cells stimulated with AFP retain their full capacity to respond in mixed lymphocytes culture (MLC) and cell-mediated lympholysis. However, AFP provokes major changes in the functional status of monocyte-enriched, MLC-stimulating cell population. This monocyte-enriched population induces $\mathrm{T}$ suppressor cells while at the same time, suppresses generation of cytotoxic T cells (156-158).

Pregnancy-associated hormones not only affect conventional $\mathrm{T}$ cells but have also been shown to support the generation and function of Treg cells. Treg cells represent a specialized subset within the $\mathrm{T}$ cell compartment with unique properties. During pregnancy, they are fundamentally involved in the suppression of alloreactive immune responses and, thus their absence results in worse pregnancy outcome both in humans (159) and mice (160). The presence of Treg cells in the uterus before pregnancy seems to be very relevant as well. A diminished endometrial expression of their major transcription factor Foxp3 is associated with infertility in women (161) while depletion of Treg cells in a murine model derived in a hostile uterine microenvironment hindered the implantation of the embryo (162). During the reproductive cycle, Treg cells fluctuate (162-164) and this was suggested to be hormone-driven (165). This could be interpreted as hormones preparing the mother and particularly the tissue for pregnancy. Already in the 80s hCG was assumed to induce human and murine suppressor T lymphocytes (166-168). Nowadays, steroid hormones and gonadotropins are proposed to regulate several aspects of Treg cell biology, including generation, expansion, migration, and suppressive function both in humans and mice (103, 145, 169-176). However, some studies provide evidence that P4 and E2 induce a reduction of Treg cells or did not provoke changes in the number of Treg cells (177-179). Thus, these contradictory findings may depend on the markers used to define Treg cells, the time point of analysis and the model used. Hence, more research is needed to understand at which time point and through, which mechanisms pregnancy hormones influence Treg cell function. Hormonal effects on T cells are summarized in Figures 2 and 3.

\section{THERAPEUTIC POTENTIAL OF PREGNANCY-ASSOCIATED HORMONES IN ASSISTED REPRODUCTIVE TECHNIQUES}

Immunological disorders have been suggested as one of the major reasons for unexplained infertility, implantation failures, and recurrent pregnancy loss. It has been discussed that alteration in the number and function of immune cell populations during the reproductive cycle and in early pregnancy stages may result in the inability to become pregnant and in worse pregnancy outcome. Women undergoing assisted reproductive techniques (ART) often present recurrent implantation failures after in vitro fertilization (IVF) and embryo transfer (ET). Hormonal treatment with steroid hormones and gonadotropins before and after ART was shown to support successful implantation and thereby improve pregnancy rates $(26,180-182)$. Based on the data discussed here, it can be speculated that hormonal treatment in ART counteract immunological disorders and may therefore, at least partially explain improved pregnancy rates. By affecting immune cell populations and their products, hormones are suggested to influence the local environment and thereby support an optimal implantation of the embryo (3). Lukassen and colleagues showed that hormonal stimulation for IVF treatment positively affected the $\mathrm{CD} 56^{\text {bright }} / \mathrm{CD} 56^{\mathrm{dim}}$ ratio in the endometrium by a relative decrease in the cytotoxic $\mathrm{CD} 56^{\mathrm{dim}} \mathrm{CD} 16^{+} \mathrm{NK}$ cell number. Moreover, the same authors observed an increase in B cells and macrophages and these effects were restricted to the endometrium and could not be observed in peripheral blood (183). By doing so, hormones may contribute to tissue remodeling and angiogenesis resulting in a proper placentation and fetal nourishment. The positive effect of hCG on ART is underlined by a study of Mansour and colleagues who showed that intrauterine injection of hCG before ET in patients undergoing IVF significantly improved implantation and pregnancy rates (180). Unfortunately, the authors did not analyze the number and activity of Treg cells although augmented pregnancy rates after IVF have been associated with elevated Treg cell numbers in peripheral blood (184). Interestingly, based on our observation that hCG efficiently attracts Treg cells to trophoblasts (145), the Egyptian IVF-ET Center conducted a clinical trial investigating the effect of intrauterine injection of hCG on endometrial Treg cells. Upcoming results will prove whether hCG treatment around implantation time may increase endogenous endometrial Treg cell levels and thereby favor the implantation process.

\section{CONCLUSION}

Altogether, an exhaustive analysis of the literature indicates a crucial role for sex hormones on a variety of immune cell populations building up a complex network of interactions between the endocrine and the immune system. Irritations in this fine regulated balance may result in implantation failure and undesired pregnancy outcome. Thus, further investigations on the immune modulating functions of pregnancy-associated hormones will improve our understanding of endocrine-immune interactions before and during pregnancy and may help to develop selective strategies in the treatment of infertility and pregnancy complications. 


\section{REFERENCES}

1. Chambers SP, Clarke AG. Measurement of thymus weight, lumbar node weight and progesterone levels in syngeneically pregnant, allogeneically pregnant, and pseudopregnant mice. J Reprod Fertil (1979) 55(2):309-15. doi:10.1530/jrf.0. 0550309

2. Stewart DR, Overstreet JW, Nakajima ST, Lasley BL. Enhanced ovarian steroid secretion before implantation in early human pregnancy. J Clin Endocrinol Metab (1993) 76(6):1470-6. doi:10.1210/jcem.76.6.8501152

3. Szekeres-Bartho J, Balasch J. Progestogen therapy for recurrent miscarriage. Hum Reprod Update (2008) 14(1):27-35. doi:10.1093/humupd/dmm035

4. Norwitz ER, Schust DJ, Fisher SJ. Implantation and the survival of early pregnancy. N Engl J Med (2001) 345(19):1400-8. doi:10.1056/NEJMra000763

5. Costea DM, Gunn LK, Hargreaves C, Howell RJ, Chard T. Delayed luteoplacental shift of progesterone production in IVF pregnancy. Int J Gynaecol Obstet (2000) 68(2):123-9. doi:10.1016/S0020-7292(99)00177-0

6. Mendelson CR. Minireview: fetal-maternal hormonal signaling in pregnancy and labor. Mol Endocrinol (2009) 23(7):947-54. doi:10.1210/me.2009-0016

7. Ramathal CY, Bagchi IC, Taylor RN, Bagchi MK. Endometrial decidualization: of mice and men. Semin Reprod Med (2010) 28(1):17-26. doi:10.1055/s-00291242989

8. Goldman S, Shalev E. Progesterone receptor profile in the decidua and fetal membrane. Front Biosci (2007) 12:634-48. doi:10.2741/2088

9. Kowalik MK, Rekawiecki R, Kotwica J. The putative roles of nuclear and membrane-bound progesterone receptors in the female reproductive tract. Reprod Biol (2013) 13(4):279-89. doi:10.1016/j.repbio.2013.09.001

10. Szekeres-Bartho J, Wilczynski JR, Basta P, Kalinka J. Role of progesterone and progestin therapy in threatened abortion and preterm labour. Front Biosci (2008) 13:1981-90. doi:10.2741/2817

11. Alok A, Mukhopadhyay D, Karande AA. Glycodelin A, an immunomodulatory protein in the endometrium, inhibits proliferation and induces apoptosis in monocytic cells. Int J Biochem Cell Biol (2009) 41(5):1138-47. doi:10.1016/j.biocel.2008.10.009

12. Ozawa H. Steroid hormones, their receptors and neuroendocrine system. JNippon Med Sch (2005) 72(6):316-25. doi:10.1272/jnms.72.316

13. Mihm M, Gangooly S, Muttukrishna S. The normal menstrual cycle in women. Anim Reprod Sci (2011) 124(3-4):229-36. doi:10.1016/j.anireprosci. 2010.08.030

14. Pasqualini JR. Enzymes involved in the formation and transformation of steroid hormones in the fetal and placental compartments. J Steroid Biochem Mol Biol (2005) 97(5):401-15. doi:10.1016/j.jsbmb.2005.08.004

15. Levin ER. Integration of the extranuclear and nuclear actions of estrogen. Mol Endocrinol (2005) 19(8):1951-9. doi:10.1210/me.2004-0390

16. Salem ML. Estrogen, a double-edged sword: modulation of TH1- and TH2mediated inflammations by differential regulation of TH1/TH2 cytokine production. Curr Drug Targets Inflamm Allergy (2004) 3(1):97-104. doi:10.2174/ 1568010043483944

17. Mao A, Paharkova-Vatchkova V, Hardy J, Miller MM, Kovats S. Estrogen selectively promotes the differentiation of dendritic cells with characteristics of Langerhans cells. J Immunol (2005) 175(8):5146-51. doi:10.4049/jimmunol. 175.8.5146

18. Cole LA. Biological functions of hCG and hCG-related molecules. Reprod Biol Endocrinol (2010) 8(1):102. doi:10.1186/1477-7827-8-102

19. Braunstein GD, Rasor J, Danzer H, Adler D, Wade ME. Serum human chorionic gonadotropin levels throughout normal pregnancy. Am J Obstet Gynecol (1976) 126(6):678-81.

20. Handschuh K, Guibourdenche J, Tsatsaris V, Guesnon M, Laurendeau I, Evain-Brion D, et al. Human chorionic gonadotropin expression in human trophoblasts from early placenta: comparative study between villous and extravillous trophoblastic cells. Placenta (2007) 28(2-3):175-84. doi:10.1016/ j.placenta.2006.01.019

21. Fluhr H, Bischof-Islami D, Krenzer S, Licht P, Bischof P, Zygmunt M. Human chorionic gonadotropin stimulates matrix metalloproteinases-2 and -9 in cytotrophoblastic cells and decreases tissue inhibitor of metalloproteinases$1,-2$, and -3 in decidualized endometrial stromal cells. Fertil Steril (2008) 90(4):1390-5. doi:10.1016/j.fertnstert.2007.08.023

22. Környei JL, Lei ZM, Rao CV. Human myometrial smooth muscle cells are novel targets of direct regulation by human chorionic gonadotropin. Biol Reprod (1993) 49(6):1149-57. doi:10.1095/biolreprod49.6.1149
23. Kayisli UA, Selam B, Guzeloglu-Kayisli O, Demir R, Arici A. Human chorionic gonadotropin contributes to maternal immunotolerance and endometrial apoptosis by regulating Fas-Fas ligand system. J Immunol (2003) 171(5):2305-13. doi:10.4049/jimmunol.171.5.2305

24. Berndt S, Perrier d'Hauterive S, Blacher S, Péqueux C, Lorquet S, Munaut C, et al. Angiogenic activity of human chorionic gonadotropin through LH receptor activation on endothelial and epithelial cells of the endometrium. FASEB J (2006) 20(14):2630-2. doi:10.1096/fj.06-5885fje

25. Zygmunt M, Herr F, Keller-Schoenwetter S, Kunzi-Rapp K, Münstedt K, Rao CV, et al. Characterization of human chorionic gonadotropin as a novel angiogenic factor. J Clin Endocrinol Metab (2002) 87(11):5290-6. doi:10.1210/ jc. 2002-020642

26. Fujimoto A, Osuga Y, Fujiwara T, Yano T, Tsutsumi O, Momoeda M, et al. Human chorionic gonadotropin combined with progesterone for luteal support improves pregnancy rate in patients with low late-midluteal estradiol levels in IVF cycles. J Assist Reprod Genet (2002) 19(12):550-4. doi:10.1023/A: 1021207014429

27. Lafuste P, Robert B, Mondon F, Danan JL, Rossi B, Duc-Goiran P, et al. Alphafetoprotein gene expression in early and full-term human trophoblast. Placenta (2002) 23(8-9):600-12. doi:10.1053/plac.2002.0816

28. Tomasi TB. Structure and function of alpha-fetoprotein. Annu Rev Med (1977) 28:453-65. doi:10.1146/annurev.me.28.020177.002321

29. Laan-Pütsep K, Wigzell H, Cotran P, Gidlund M. Human alpha-fetoprotein (AFP) causes a selective down regulation of monocyte MHC class II molecules without altering other induced or noninduced monocyte markers or functions in monocytoid cell lines. Cell Immunol (1991) 133(2):506-18. doi:10.1016/0008-8749(91)90122-R

30. Chakraborty M, Mandal C. Immuno-suppressive effect of human alphafetoprotein: a cross species study. Immunol Invest (1993) 22(5):329-39. doi:10. 3109/08820139309063412

31. Wang W, Alpert E. Downregulation of phorbol 12-myristate 13-acetateinduced tumor necrosis factor-alpha and interleukin-1 beta production and gene expression in human monocytic cells by human alpha-fetoprotein. Hepatology (1995) 22(3):921-8. doi:10.1002/hep.1840220333

32. Um SH, Mulhall C, Alisa A, Ives AR, Karani J, Williams R, et al. Alphafetoprotein impairs APC function and induces their apoptosis. J Immunol (2004) 173(3):1772-8. doi:10.4049/jimmunol.173.3.1772

33. Tonello A, Poli G. Tubal ectopic pregnancy: macrophages under the microscope. Hum Reprod (2007) 22(10):2577-84. doi:10.1093/humrep/dem246

34. Zhang YM, Rao CV, Lei ZM. Macrophages in human reproductive tissues contain luteinizing hormone/chorionic gonadotropin receptors. Am J Reprod Immunol (2003) 49(2):93-100. doi:10.1034/j.1600-0897.2003.00013.x

35. Bukovsky A, Indrapichate K, Fujiwara H, Cekanova M, Ayala ME, Dominguez $\mathrm{R}$, et al. Multiple luteinizing hormone receptor (LHR) protein variants, interspecies reactivity of anti-LHR mAb clone 3B5, subcellular localization of LHR in human placenta, pelvic floor and brain, and possible role for LHR in the development of abnormal pregnancy, pelvic floor disorders and Alzheimer's disease. Reprod Biol Endocrinol (2003) 1:46. doi:10.1186/1477-7827-1-46

36. Hunt JS, Miller L, Platt JS. Hormonal regulation of uterine macrophages. Dev Immunol (1998) 6(1-2):105-10. doi:10.1155/1998/87527

37. Kitzmiller JL, Rocklin RE. Lack of suppression of lymphocyte MIF production by estradiol, progesterone and human chorionic gonadotropin. J Reprod Immunol (1980) 1(5-6):297-306. doi:10.1016/0165-0378(80)90003-0

38. Cervar M, Blaschitz A, Dohr G, Desoye G. Paracrine regulation of distinct trophoblast functions in vitro by placental macrophages. Cell Tissue Res (1999) 295(2):297-305. doi:10.1007/s004410051236

39. Kanda N, Watanabe S. Regulatory roles of sex hormones in cutaneous biology and immunology. J Dermatol Sci (2005) 38(1):1-7. doi:10.1016/j.jdermsci. 2004.10.011

40. Guimerà M, Morales-Ruiz M, Jiménez W, Balasch J. LH/HCG stimulation of VEGF and adrenomedullin production by follicular fluid macrophages and luteinized granulosa cells. Reprod Biomed Online (2009) 18(6):743-9. doi:10.1016/S1472-6483(10)60021-1

41. Polan ML, Kuo A, Loukides J, Bottomly K. Cultured human luteal peripheral monocytes secrete increased levels of interleukin-1. J Clin Endocrinol Metab (1990) 70(2):480-4. doi:10.1210/jcem-70-2-480

42. Kim HM, Moon YH. Human chorionic gonadotropin induces nitric oxide synthase mRNA in mouse peritoneal macrophages. Biochem Biophys Res Commun (1996) 229(2):548-52. doi:10.1006/bbrc.1996.1841 
43. Sun Y, Cai J, Ma F, Lü P, Huang H, Zhou J. miR-155 mediates suppressive effect of progesterone on TLR3, TLR4-triggered immune response. Immunol Lett (2012) 146(1-2):25-30. doi:10.1016/j.imlet.2012.04.007

44. Menzies FM, Henriquez FL, Alexander J, Roberts CW. Selective inhibition and augmentation of alternative macrophage activation by progesterone. Immunology (2011) 134(3):281-91. doi:10.1111/j.1365-2567.2011.03488.x

45. Wan H, Versnel MA, Cheung WY, Leenen PJM, Khan NA, Benner R, et al. Chorionic gonadotropin can enhance innate immunity by stimulating macrophage function. J Leukoc Biol (2007) 82(4):926-33. doi:10.1189/jlb.0207092

46. Abu Alshamat E, Al-Okla S, Soukkarieh CH, Kweider M. Human chorionic gonadotrophin (hCG) enhances immunity against $L$. tropica by stimulating human macrophage functions. Parasite Immunol (2012) 34(10):449-54. doi:10.1111/j.1365-3024.2012.01368.x

47. Sonoda N, Katabuchi H, Tashiro H, Ohba T, Nishimura R, Minegishi T, et al. Expression of variant luteinizing hormone/chorionic gonadotropin receptors and degradation of chorionic gonadotropin in human chorionic villous macrophages. Placenta (2005) 26(4):298-307. doi:10.1016/j.placenta. 2004.07.001

48. Katabuchi H, Ohba T. Human chorionic villous macrophages as a fetal biological shield from maternal chorionic gonadotropin. Dev Growth Differ (2008) 50(5):299-306. doi:10.1111/j.1440-169X.2008.01030.x

49. Yamaguchi M, Ohba T, Tashiro H, Yamada G, Katabuchi H. Human chorionic gonadotropin induces human macrophages to form intracytoplasmic vacuoles mimicking Hofbauer cells in human chorionic villi. Cells Tissues Organs (2013) 197(2):127-35. doi:10.1159/000342806

50. Lu CY, Changelian PS, Unanue ER. Alpha-fetoprotein inhibits macrophage expression of Ia antigens. J Immunol (1984) 132(4):1722-7.

51. Hatta K, Carter AL, Chen Z, Leno-Duran E, Ruiz-Ruiz C, Olivares EG, et al. Expression of the vasoactive proteins AT1, AT2, and ANP by pregnancyinduced mouse uterine natural killer cells. Reprod Sci (2011) 18(4):383-90. doi:10.1177/1933719110385136

52. Wang C, Umesaki N, Nakamura H, Tanaka T, Nakatani K, Sakaguchi I, et al. Expression of vascular endothelial growth factor by granulated metrial gland cells in pregnant murine uteri. Cell Tissue Res (2000) 300(2):285-93. doi:10.1007/s004410000198

53. Tayade C, Hilchie D, He H, Fang Y, Moons L, Carmeliet P, et al. Genetic deletion of placenta growth factor in mice alters uterine NK cells. J Immunol (2007) 178(7):4267-75. doi:10.4049/jimmunol.178.7.4267

54. Ashkar AA, Croy BA. Functions of uterine natural killer cells are mediated by interferon gamma production during murine pregnancy. Semin Immunol (2001) 13(4):235-41. doi:10.1006/smim.2000.0319

55. Borzychowski AM, Chantakru S, Minhas K, Paffaro VA, Yamada AT, He H, et al. Functional analysis of murine uterine natural killer cells genetically devoid of oestrogen receptors. Placenta (2003) 24(4):403-11. doi:10.1053/plac.2002. 0924

56. van den Heuvel MJ, Horrocks J, Bashar S, Taylor S, Burke S, Hatta K, et al. Menstrual cycle hormones induce changes in functional interactions between lymphocytes and decidual vascular endothelial cells. J Clin Endocrinol Metab (2005) 90(5):2835-42. doi:10.1210/jc.2004- 1742

57. Carlino C, Stabile H, Morrone S, Bulla R, Soriani A, Agostinis C, et al. Recruitment of circulating NK cells through decidual tissues: a possible mechanism controlling NK cell accumulation in the uterus during early pregnancy. Blood (2008) 111(6):3108-15. doi:10.1182/blood-2007-08-105965

58. Kuang H, Peng H, Xu H, Zhang B, Peng J, Tan Y. Hormonal regulation of uterine natural killer cells in mouse preimplantation uterus. J Mol Histol (2010) 41(1):1-7. doi:10.1007/s10735-010-9256-8

59. Inoue $T$, Kanzaki H, Imai K, Narukawa S, Katsuragawa H, Watanabe H, et al. Progesterone stimulates the induction of human endometrial CD56+ lymphocytes in an in vitro culture system. J Clin Endocrinol Metab (1996) 81(4):1502-7. doi:10.1210/jcem.81.4.8636358

60. Qu X, Yang M, Zhang W, Liang L, Yang Y, Zhang Y, et al. Osteopontin expression in human decidua is associated with decidual natural killer cells recruitment and regulated by progesterone. In vivo (2008) 22(1):55-61.

61. van den Heuvel MJ, Xie X, Tayade C, Peralta C, Fang Y, Leonard S, et al. A review of trafficking and activation of uterine natural killer cells. Am J Reprod Immunol (2005) 54(6):322-31. doi:10.1111/j.1600-0897.2005.00336.x

62. King A, Gardner L, Loke YW. Evaluation of oestrogen and progesterone receptor expression in uterine mucosal lymphocytes. Hum Reprod (1996) 11(5):1079-82. doi:10.1093/oxfordjournals.humrep.a019300
63. Henderson TA, Saunders PTK, Moffett-King A, Groome NP, Critchley HOD. Steroid receptor expression in uterine natural killer cells. J Clin Endocrinol Metab (2003) 88(1):440-9. doi:10.1210/jc.2002-021174

64. Oh M-J, Croy B. A map of relationships between uterine natural killer cells and progesterone receptor expressing cells during mouse pregnancy. Placenta (2008) 29(4):317-23. doi:10.1016/j.placenta.2008.01.003

65. Guo W, Li P, Zhao G, Fan H, Hu Y, Hou Y. Glucocorticoid receptor mediates the effect of progesterone on uterine natural killer cells. Am J Reprod Immunol (2012) 67(6):463-73. doi:10.1111/j.1600-0897.2012.01114.x

66. Kane N, Kelly R, Saunders PTK, Critchley HOD. Proliferation of uterine natural killer cells is induced by human chorionic gonadotropin and mediated via the mannose receptor. Endocrinology (2009) 150(6):2882-8. doi:10.1210/en.2008-1309

67. Hansen KA, Opsahl MS, Nieman LK, Baker JR, Klein TA. Natural killer cell activity from pregnant subjects is modulated by RU 486. Am J Obstet Gynecol (1992) 166(1 Pt 1):87-90. doi:10.1016/0002-9378(92)91835-X

68. Szekeres-Bartho J, Barakonyi A, Polgar B, Par G, Faust Z, Palkovics T, et al. The role of gamma/delta $T$ cells in progesterone-mediated immunomodulation during pregnancy: a review. Am J Reprod Immunol (1999) 42(1):44-8. doi:10.1111/j.1600-0897.1999.tb00464.x

69. Faust Z, Laskarin G, Rukavina D, Szekeres-Bartho J. Progesterone-induced blocking factor inhibits degranulation of natural killer cells. Am J Reprod Immunol (1999) 42(2):71-5.

70. Laskarin G, Tokmadzic VS, Strbo N, Bogovic T, Szekeres-Bartho J, Randic $\mathrm{L}$, et al. Progesterone induced blocking factor (PIBF) mediates progesterone induced suppression of decidual lymphocyte cytotoxicity. Am J Reprod Immunol (2002) 48(4):201-9. doi:10.1034/j.1600-0897.2002.01133.x

71. Gabrilovac J, Zadjelovic J, Osmak M, Suchanek E, Zupanovic Z, Boranic M. NK cell activity and estrogen hormone levels during normal human pregnancy. Gynecol Obstet Invest (1988) 25(3):165-72. doi:10.1159/000293766

72. Hao S, Zhao J, Zhou J, Zhao S, Hu Y, Hou Y. Modulation of 17betaestradiol on the number and cytotoxicity of NK cells in vivo related to MCM and activating receptors. Int Immunopharmacol (2007) 7(13):1765-75. doi:10.1016/j.intimp.2007.09.017

73. Kurashige T, Morita H, Ogura H, Kurashige M, Kitamura I, Kamimura O. The effects of hormone and protein increases during pregnancy on natural killer (NK) cell activity. Asia Oceania J Obstet Gynaecol (1986) 12(3):403-7. doi:10.1111/j.1447-0756.1986.tb00211.x

74. Kitaya K, Yasuda J, Nakayama T, Fushiki S, Honjo H. Effect of female sex steroids on human endometrial CD16neg CD56bright natural killer cells. Fertil Steril (2003) 79(Suppl 1):730-4. doi:10.1016/S0015-0282(02)04818-5

75. Papademetriou V, Bartocci A, Stylos WA, Chirigos MA. Augmentation of cytotoxicity by splenic cells of pregnant or human chorionic gonadotropintreated normal mice. J Immunopharmacol (1980) 2(3):309-24. doi:10.3109/ 08923978009046464

76. Sulke AN, Jones DB, Wood PJ. Hormonal modulation of human natural killer cell activity in vitro. J Reprod Immunol (1985) 7(2):105-10. doi:10.1016/01650378(85)90064-6

77. Alexander H, Zimmermann G, Lehmann M, Pfeiffer R, Schöne E, Leiblein $\mathrm{S}$, et al. HCG secretion by peripheral mononuclear cells during pregnancy. Domest Anim Endocrinol (1998) 15(5):377-87. doi:10.1016/S0739-7240(98) 00025-3

78. Alvarez-Errico D, Lessmann E, Rivera J. Adapters in the organization of mast cell signaling. Immunol Rev (2009) 232(1):195-217. doi:10.1111/j.1600-065X. 2009.00834.x

79. Shelburne CP, Abraham SN. The mast cell in innate and adaptive immunity. Adv Exp Med Biol (2011) 716:162-85. doi:10.1007/978-1-4419-9533-9_10

80. Woidacki K, Popovic M, Metz M, Schumacher A, Linzke N, Teles A, et al. Mast cells rescue implantation defects caused by c-kit deficiency. Cell Death Dis (2013) 4(1):e462. doi:10.1038/cddis.2012.214

81. Mori A, Zhai YL, Toki T, Nikaido T, Fujii S. Distribution and heterogeneity of mast cells in the human uterus. Hum Reprod (1997) 12(2):368-72. doi:10.1093/humrep/12.2.368

82. Padilla L, Reinicke K, Montesino H, Villena F, Asencio H, Cruz M, et al. Histamine content and mast cells distribution in mouse uterus: the effect of sexual hormones, gestation and labor. Cell Mol Biol (1990) 36(1):93-100.

83. Gibbons AF, Chang MC. Number of mast cells in the rat uterus with special reference to its relation to hormonal treatment and decidual response. Biol Reprod (1972) 6(2):193-203. 
84. Wordinger RJ, Orr EL, Pace K, Oakford L, Morrill A. An assessment of mastcell deficient mice (W/Wv) as a model system to study the role of histamine in implantation and deciduoma formation. J Reprod Fertil (1985) 73(2):451-6. doi:10.1530/jrf.0.0730451

85. Jing $H$, Wang $Z$, Chen Y. Effect of oestradiol on mast cell number and histamine level in the mammary glands of rat. Anat Histol Embryol (2012) 41(3):170-6. doi:10.1111/j.1439-0264.2011.01120.x

86. Jensen F, Woudwyk M, Teles A, Woidacki K, Taran F, Costa S, et al. Estradiol and progesterone regulate the migration of mast cells from the periphery to the uterus and induce their maturation and degranulation. PLoS One (2010) 5(12):e14409. doi:10.1371/journal.pone.0014409

87. Chancey AL, Gardner JD, Murray DB, Brower GL, Janicki JS. Modulation of cardiac mast cell-mediated extracellular matrix degradation by estrogen. Am J Physiol Heart Circ Physiol (2005) 289(1):H316-21. doi:10.1152/ajpheart.00765. 2004

88. Vasiadi M, Kempuraj D, Boucher W, Kalogeromitros D, Theoharides TC. Progesterone inhibits mast cell secretion. Int J Immunopathol Pharmacol (2006) 19(4):787-94.

89. Zaitsu M, Narita S-I, Lambert KC, Grady JJ, Estes DM, Curran EM, et al. Estradiol activates mast cells via a non-genomic estrogen receptor-alpha and calcium influx. Mol Immunol (2007) 44(8):1977-85. doi:10.1016/j.molimm.2006. 09.030

90. Narita S-I, Goldblum RM, Watson CS, Brooks EG, Estes DM, Curran EM, et al. Environmental estrogens induce mast cell degranulation and enhance IgE-mediated release of allergic mediators. Environ Health Perspect (2007) 115(1):48-52. doi:10.1289/ehp.9378

91. Bergman F, Damber MG, Lindén U, Paul KG. Mast cells and eosinophil granulocytes in the oestrogen-stimulated mouse uterus. Acta Endocrinol (1972) 69(1):77-86.

92. Cocchiara R, Albeggiani G, Di Trapani G, Azzolina A, Lampiasi N, Rizzo F, et al. Oestradiol enhances in vitro the histamine release induced by embryonic histamine-releasing factor (EHRF) from uterine mast cells. Hum Reprod (1992) 7(8):1036-41.

93. Hunt JS, Miller L, Roby KF, Huang J, Platt JS, DeBrot BL. Female steroid hormones regulate production of pro-inflammatory molecules in uterine leukocytes. J Reprod Immunol (1997) 35(2):87-99. doi:10.1016/S0165-0378(97) 00060-0

94. Theoharides TC, Dimitriadou V, Letourneau R, Rozniecki JJ, Vliagoftis H, Boucher W. Synergistic action of estradiol and myelin basic protein on mast cell secretion and brain myelin changes resembling early stages of demyelination. Neuroscience (1993) 57(3):861-71. doi:10.1016/0306-4522(93)90030-J

95. Erlik Y, Naot Y, Friedman M, Ben-David E, Paldi E. Histamine levels in ovarian hyperstimulation syndrome. Obstet Gynecol (1979) 53(5):580-2.

96. Kämmerer U, Eggert AO, Kapp M, McLellan AD, Geijtenbeek TBH, Dietl J, et al. Unique appearance of proliferating antigen-presenting cells expressing DC-SIGN (CD209) in the decidua of early human pregnancy. Am J Pathol (2003) 162(3):887-96. doi:10.1016/S0002-9440(10)63884-9

97. Blois SM, Alba Soto CD, Tometten M, Klapp BF, Margni RA, Arck PC. Lineage, maturity, and phenotype of uterine murine dendritic cells throughout gestation indicate a protective role in maintaining pregnancy. Biol Reprod (2004) 70(4):1018-23. doi:10.1095/biolreprod.103.022640

98. Blois S, Tometten M, Kandil J, Hagen E, Klapp BF, Margni RA, et al. Intercellular adhesion molecule-1/LFA- 1 cross talk is a proximate mediator capable of disrupting immune integration and tolerance mechanism at the fetomaternal interface in murine pregnancies. J Immunol (2005) 174(4):1820-9. doi:10.4049/jimmunol.174.4.1820

99. Askelund K, Liddell HS, Zanderigo AM, Fernando NS, Khong TY, Stone $\mathrm{PR}$, et al. CD83(+) dendritic cells in the decidua of women with recurrent miscarriage and normal pregnancy. Placenta (2004) 25(2-3):140-5. doi:10.1016/S0143-4004(03)00182-6

100. Plaks V, Birnberg T, Berkutzki T, Sela S, BenYashar A, Kalchenko V, et al. Uterine DCs are crucial for decidua formation during embryo implantation in mice. J Clin Invest (2008) 12:3954-65. doi:10.1172/JCI36682

101. Butts CL, Shukair SA, Duncan KM, Bowers E, Horn C, Belyavskaya E, et al. Progesterone inhibits mature rat dendritic cells in a receptor-mediated fashion. Int Immunol (2007) 19(3):287-96. doi:10.1093/intimm/dxl145

102. Kovats S. Estrogen receptors regulate an inflammatory pathway of dendritic cell differentiation: mechanisms and implications for immunity. Horm Behav (2012) 62(3):254-62. doi:10.1016/j.yhbeh.2012.04.011
103. Schumacher A, Heinze K, Witte J, Poloski E, Linzke N, Woidacki K, et al. Human chorionic gonadotropin as a central regulator of pregnancy immune tolerance. J Immunol (2013) 190(6):2650-8. doi:10.4049/jimmunol.1202698

104. Xu Y, He H, Li C, Shi Y, Wang Q, Li W, et al. Immunosuppressive effect of progesterone on dendritic cells in mice. J Reprod Immunol (2011) 91(1-2):17-23. doi:10.1016/j.jri.2011.06.101

105. Wan H, Versnel MA, Leijten LME, van Helden-Meeuwsen CG, Fekkes D, Leenen PJM, et al. Chorionic gonadotropin induces dendritic cells to express a tolerogenic phenotype. J Leukoc Biol (2008) 83(4):894-901. doi:10.1189/jlb. 0407258

106. Huck B, Steck T, Habersack M, Dietl J, Kämmerer U. Pregnancy associated hormones modulate the cytokine production but not the phenotype of PBMC-derived human dendritic cells. Eur J Obstet Gynecol Reprod Biol (2005) 122(1):85-94. doi:10.1016/j.ejogrb.2005.02.017

107. Uemura Y, Liu T-Y, Narita Y, Suzuki M, Matsushita S. 17 $\beta$-Estradiol (E2) plus tumor necrosis factor- $\alpha$ induces a distorted maturation of human monocytederived dendritic cells and promotes their capacity to initiate T-helper 2 responses. Hum Immunol (2008) 69(3):149-57. doi:10.1016/j.humimm.2008. 01.017

108. Segerer SE, Müller N, van Den Brandt J, Kapp M, Dietl J, Reichardt HM, et al. Impact of female sex hormones on the maturation and function of human dendritic cells. Am J Reprod Immunol (2009) 62(3):165-73. doi:10.1111/j.16000897.2009.00726.x

109. Kyurkchiev D, Ivanova-Todorova E, Hayrabedyan S, Altankova I, Kyurkchiev S. Female sex steroid hormones modify some regulatory properties of monocytederived dendritic cells. Am J Reprod Immunol (2007) 58(5):425-33. doi:10. 1111/j.1600-0897.2007.00526.x

110. Xiao B-G, Liu X, Link H. Antigen-specific T cell functions are suppressed over the estrogen-dendritic cell-indoleamine 2,3-dioxygenase axis. Steroids (2004) 69(10):653-9. doi:10.1016/j.steroids.2004.05.019

111. Zhu WH, Lu CZ, Huang YM, Link H, Xiao BG. A putative mechanism on remission of multiple sclerosis during pregnancy: estrogen-induced indoleamine 2,3-dioxygenase by dendritic cells. Mult Scler (2007) 13(1):33-40. doi:10.1177/ 1352458506071171

112. Ueno A, Cho S, Cheng L, Wang J, Hou S, Nakano H, et al. Transient upregulation of indoleamine 2,3-dioxygenase in dendritic cells by human chorionic gonadotropin downregulates autoimmune diabetes. Diabetes (2007) 56(6):1686-93. doi:10.2337/db06-1727

113. Negishi Y, Wakabayashi A, Shimizu M, Ichikawa T, Kumagai Y, Takeshita T, et al. Disruption of maternal immune balance maintained by innate DC subsets results in spontaneous pregnancy loss in mice. Immunobiology (2012) 217(10):951-61. doi:10.1016/j.imbio.2012.01.011

114. Harimoto H, Shimizu M, Nakagawa Y, Nakatsuka K, Wakabayashi A, Sakamoto $\mathrm{C}$, et al. Inactivation of tumor-specific CD8+ CTLs by tumor-infiltrating tolerogenic dendritic cells. Immunol Cell Biol (2013) 91(9):545-55. doi:10. 1038/icb.2013.38

115. Porakishvili N, Mageed R, Jamin C, Pers JO, Kulikova N, Renaudineau Y, et al. Recent progress in the understanding of B-cell functions in autoimmunity. Scand J Immunol (2001) 54(1-2):30-8. doi:10.1046/j.1365-3083.2001.00950.x

116. Youinou P, Jamin C, Pers J-O, Berthou C, Saraux A, Renaudineau Y. B lymphocytes are required for development and treatment of autoimmune diseases. Ann N Y Acad Sci (2005) 1050:19-33. doi:10.1196/annals.1313.003

117. Muzzio D, Zenclussen AC, Jensen F. The role of B cells in pregnancy: the good and the bad. Am J Reprod Immunol (2013) 69(4):408-12. doi:10.1111/aji.12079

118. LeBien TW, Tedder TF. B lymphocytes: how they develop and function. Blood (2008) 112(5):1570-80. doi:10.1182/blood-2008-02-078071

119. Kantor AB, Stall AM, Adams S, Herzenberg LA. Differential development of progenitor activity for three B-cell lineages. Proc Natl Acad Sci U S A (1992) 89(8):3320-4. doi:10.1073/pnas.89.8.3320

120. Montecino-Rodriguez E, Dorshkind K. New perspectives in B-1 B cell development and function. Trends Immunol (2006) 27(9):428-33. doi:10.1016/j.it. 2006.07.005

121. Duan B, Morel L. Role of B-1a cells in autoimmunity. Autoimmun Rev (2006) 5(6):403-8. doi:10.1016/j.autrev.2005.10.007

122. Jensen F, Wallukat G, Herse F, Budner O, El-Mousleh T, Costa S-D, et al. CD19+CD5+ cells as indicators of preeclampsia. Hypertension (2012) 59(4):861-8. doi:10.1161/HYPERTENSIONAHA.111.188276

123. Hammarström L, Fuchs T, Smith CI. The immunodepressive effect of human glucoproteins and their possible role in the nonrejection process during 
pregnancy. Acta Obstet Gynecol Scand (1979) 58(5):417-22. doi:10.3109/ 00016347909154059

124. Nikolaevich KN, Ivanovich SJ, Victorovich SS. Major reproduction hormones as regulators of cell-to-cell interactions in humoral immune responses. Brain Behav Immun (1991) 5(2):149-61. doi:10.1016/0889-1591(91)90013-Z

125. Margni RA, Paz CB, Cordal ME. Immunochemical behavior of sheep nonprecipitating antibodies isolated by immunoadsorption. Immunochemistry (1976) 13(3):209-14. doi:10.1016/0019-2791(76)90217-2

126. Malan Borel I, Gentile T, Angelucci J, Pividori J, Guala MC, Binaghi RA, et al. IgG asymmetric molecules with antipaternal activity isolated from sera and placenta of pregnant human. J Reprod Immunol (1991) 20(2):129-40. doi:10.1016/0165-0378(91)90029-P

127. Zenclussen AC, Gentile T, Kortebani G, Mazzolli A, Margni R. Asymmetric antibodies and pregnancy. Am J Reprod Immunol (2001) 45(5):289-94. doi:10.1111/j.8755-8920.2001.450504.x

128. Canellada A, Blois S, Gentile T, Margni Idehu RA. In vitro modulation of protective antibody responses by estrogen, progesterone and interleukin-6. Am J Reprod Immunol (2002) 48(5):334-43. doi:10.1034/j.1600-0897.2002.01141.x

129. Kelemen K, Bognar I, Paal M, Szekeres-Bartho J. A progesterone-induced protein increases the synthesis of asymmetric antibodies. Cell Immunol (1996) 167(1):129-34. doi:10.1006/cimm.1996.0016

130. Kincade PW, Medina KL, Smithson G. Sex hormones as negative regulators of lymphopoiesis. Immunol Rev (1994) 137:119-34. doi:10.1111/j.1600-065X. 1994.tb00661.x

131. Caldwell JL, Stites DP, Fudenberg HH. Human chorionic gonadotropin: effects of crude and purified preparations on lymphocyte responses to phytohemagglutinin and allogenenic stimulation. J Immunol (1975) 115(5):1249-53.

132. Beck D, Ginsburg H, Naot Y. The modulating effect of human chorionic gonadotropin on lymphocyte blastogenesis. Am J Obstet Gynecol (1977) 129(1):14-20.

133. Cocchiara R, Lorico A, Cefalù E, Cittadini E, Geraci D. Modulation of lymphocyte response by hormones. Acta Eur Fertil (1983) 14(3):197-201.

134. Rolle L, Memarzadeh Tehran M, Morell-García A, Raeva Y, Schumacher A, Hartig R, et al. Cutting edge: IL-10-producing regulatory B cells in early human pregnancy. Am J Reprod Immunol (2013) 70(6):448-53. doi:10.1111/aji.12157

135. Hudic I, Fatušic Z. Progesterone-induced blocking factor (PIBF) and Th1/Th2 cytokine in women with threatened spontaneous abortion. J Perinat Med (2009) 37(4):338-42. doi:10.1515/JPM.2009.061

136. Ito A, Bebo BF, Matejuk A, Zamora A, Silverman M, Fyfe-Johnson A, et al. Estrogen treatment down-regulates TNF-alpha production and reduces the severity of experimental autoimmune encephalomyelitis in cytokine knockout mice. J Immunol (2001) 167(1):542-52. doi:10.4049/jimmunol.167.1.542

137. McMurray RW, Ndebele K, Hardy KJ, Jenkins JK. 17-Beta-estradiol suppresses IL-2 and IL-2 receptor. Cytokine (2001) 14(6):324-33. doi:10.1006/ cyto. 2001.0900

138. Miyaura H, Iwata M. Direct and indirect inhibition of Th1 development by progesterone and glucocorticoids. J Immunol (2002) 168(3):1087-94. doi:10.4049/jimmunol.168.3.1087

139. Matalka KZ. The effect of estradiol, but not progesterone, on the production of cytokines in stimulated whole blood, is concentration-dependent. Neuro Endocrinol Lett (2003) 24(3-4):185-91.

140. Raghupathy R, Al Mutawa E, Makhseed M, Azizieh F, Szekeres-Bartho J. Modulation of cytokine production by dydrogesterone in lymphocytes from women with recurrent miscarriage. BJOG (2005) 112(8):1096-101. doi:10. 1111/j.1471-0528.2005.00633.x

141. Robinson DP, Klein SL. Pregnancy and pregnancy-associated hormones alter immune responses and disease pathogenesis. Horm Behav (2012) 62(3):263-71. doi:10.1016/j.yhbeh.2012.02.023

142. Pazos MA, Kraus TA, Muñoz-Fontela C, Moran TM, Deng JC. Estrogen mediates innate and adaptive immune alterations to influenza infection in pregnant mice. PLoS One (2012) 7(7):e40502. doi:10.1371/journal.pone.0040502

143. Hughes GC, Clark EA, Wong AH. The intracellular progesterone receptor regulates CD4+ T cells and T cell-dependent antibody responses. J Leukoc Biol (2013) 93(3):369-75. doi:10.1189/jlb.1012491

144. Pantaleo M, Piccinno M, Roncetti M, Mutinati M, Rizzo A, Sciorsci R. Evaluation of serum concentrations of interleukin (IL)-4, IL-10, and IL-12 during pregnancy in bitches. Theriogenology (2013) 79(6):970-3. doi:10.1016/j. theriogenology.2013.01.017
145. Schumacher A, Brachwitz N, Sohr S, Engeland K, Langwisch S, Dolaptchieva $\mathrm{M}$, et al. Human chorionic gonadotropin attracts regulatory $\mathrm{T}$ cells into the fetal-maternal interface during early human pregnancy. J Immunol (2009) 182(9):5488-94. doi:10.4049/jimmunol.0803177

146. Chen J-J, Lin DJ-Q, Liu MS-Y, Chien EJ. Non-genomic rapid responses via progesterone in human peripheral $\mathrm{T}$ cells are not indirectly mimicked by sphingosine 1-phosphate. Steroids (2013) 81:9-12. doi:10.1016/j.steroids.2013.11. 011

147. Chien EJ, Chang C-P, Lee W-F, Su T-H, Wu C-H. Non-genomic immunosuppressive actions of progesterone inhibits PHA-induced alkalinization and activation in T cells. J Cell Biochem (2006) 99(1):292-304. doi:10.1002/jcb.20858

148. Hirano S, Furutama D, Hanafusa T. Physiologically high concentrations of 17beta-estradiol enhance NF-kappaB activity in human T cells. Am J Physiol Regul Integr Comp Physiol (2007) 292(4):R1465-71. doi:10.1152/ajpregu. 00778.2006

149. SundarRaj S, Mukhopadhyay D, Karande AA. Glycodelin A triggers mitochondrial stress and apoptosis in T cells by a mechanism distinct and independent of TCR signaling. Mol Immunol (2008) 45(8):2391-400. doi:10.1016/j.molimm. 2007.11.004

150. Alok A, Karande AA. The role of glycodelin as an immune-modulating agent at the feto-maternal interface. J Reprod Immunol (2009) 83(1-2):124-7. doi:10.1016/j.jri.2009.06.261

151. Fraccaroli L, Grasso E, Zeitler E, Lombardi E, Gogorza S, Etchepareborda JJ, et al. Modulation of maternal LIF producers T cells by trophoblast and paternal antigens. Am J Reprod Immunol (2011) 65(2):133-45. doi:10.1111/j.16000897.2010.00890.x

152. Aisemberg J, Vercelli CA, Bariani MV, Billi SC, Wolfson ML, Franchi AM, et al. Progesterone is essential for protecting against LPS-induced pregnancy loss. LIF as a potential mediator of the anti-inflammatory effect of progesterone. PLoS One (2013) 8(2):e56161. doi:10.1371/journal.pone.0056161

153. Shirshev SV. Molecular mechanisms of immunomodulating effect of chorionic gonadotropin on T- and B-lymphocytes of intact spleen. Biochemistry (Mosc) (1997) 62(5):514-22.

154. Khan NA, Khan A, Savelkoul HF, Benner R. Inhibition of diabetes in NOD mice by human pregnancy factor. Hum Immunol (2001) 62(12):1315-23. doi:10.1016/S0198-8859(01)00368-8

155. Khil L-Y, Jun H-S, Kwon H, Yoo JK, Kim S, Notkins AL, et al. Human chorionic gonadotropin is an immune modulator and can prevent autoimmune diabetes in NOD mice. Diabetologia (2007) 50(10):2147-55. doi:10.1007/s00125-0070769-y

156. Dattwyler RJ, Tomasi TB. Inhibition of sensitization of T-cells by alphafetoprotein. Int J Cancer (1975) 16(6):942-5. doi:10.1002/ijc.2910160608

157. Peck AB, Murgita RA, Wigzell H. Cellular and genetic restrictions in the immunoregulatory activity of alpha-fetoprotein. III. Role of the MLCstimulating cell population in alpha-fetoprotein-induced suppression of T cellmediated cytotoxicity. J Immunol (1982) 128(3):1134-40.

158. Toder V, Blank M, Nebel L. Immunoregulatory mechanisms in pregnancy. 1. Evidence for the alpha-fetoprotein-induced generation of suppressor cells in vitro. Transplantation (1982) 33(1):41-4. doi:10.1097/00007890198201000-00009

159. Sasaki Y, Sakai M, Miyazaki S, Higuma S, Shiozaki A, Saito S. Decidual and peripheral blood CD4+CD25+ regulatory $\mathrm{T}$ cells in early pregnancy subjects and spontaneous abortion cases. Mol Hum Reprod (2004) 10(5):347-53. doi:10.1093/molehr/gah044

160. Zenclussen AC, Gerlof K, Zenclussen ML, Sollwedel A, Bertoja AZ, Ritter $\mathrm{T}$, et al. Abnormal T-cell reactivity against paternal antigens in spontaneous abortion: adoptive transfer of pregnancy-induced CD4+CD25+ T regulatory cells prevents fetal rejection in a murine abortion model. Am J Pathol (2005) 166(3):811-22. doi:10.1016/S0002-9440(10)62302-4

161. Jasper MJ, Tremellen KP, Robertson SA. Primary unexplained infertility is associated with reduced expression of the T-regulatory cell transcription factor Foxp3 in endometrial tissue. Mol Hum Reprod (2006) 12(5):301-8. doi:10.1093/molehr/gal032

162. Teles A, Schumacher A, Kühnle M-C, Linzke N, Thuere C, Reichardt P, et al. Control of uterine microenvironment by Foxp3+ cells facilitates embryo implantation. Front Immunol (2013) 4:158. doi:10.3389/fimmu.2013.00158

163. Arruvito L, Sanz M, Banham AH, Fainboim L. Expansion of CD4+CD25+ and FOXP3+ regulatory $\mathrm{T}$ cells during the follicular phase of the menstrual 
cycle: implications for human reproduction. J Immunol (2007) 178(4):2572-8. doi:10.4049/jimmunol.178.4.2572

164. Kallikourdis M, Betz AG. Periodic accumulation of regulatory T cells in the uterus: preparation for the implantation of a semi-allogeneic fetus? PLoS One (2007) 2(4):e382. doi:10.1371/journal.pone.0000382

165. Weinberg A, Enomoto L, Marcus R, Canniff J. Effect of menstrual cycle variation in female sex hormones on cellular immunity and regulation. $J$ Reprod Immunol (2011) 89(1):70-7. doi:10.1016/j.jri.2010.11.009

166. Fuchs T, Hammarström L, Smith CI, Brundin J. In vitro induction of murine suppressor T-cells by human chorionic gonadotropin. Acta Obstet Gynecol Scand (1980) 59(4):355-9. doi:10.3109/00016348009154093

167. Fuchs T, Hammarström L, Smith CI, Brundin J. In vitro induction of human suppressor $\mathrm{T}$ cells by a chorionic gonadotropin preparation. J Reprod Immunol (1981) 3(2):75-84. doi:10.1016/0165-0378(81)90012-7

168. Fuchs T, Hammarström L, Smith CI, Brundin J. Sex-dependent induction of human suppressor T cells by chorionic gonadotropin. J Reprod Immunol (1982) 4(4):185-90. doi:10.1016/0165-0378(82)90025-0

169. Polanczyk MJ, Carson BD, Subramanian S, Afentoulis M, Vandenbark AA, Ziegler SF, et al. Cutting edge: estrogen drives expansion of the CD4+CD25+ regulatory T cell compartment. J Immunol (2004) 173(4):2227-30. doi:10. 4049/jimmunol.173.4.2227

170. Prieto GA, Rosenstein Y. Oestradiol potentiates the suppressive function of human $\mathrm{CD} 4 \mathrm{CD} 25$ regulatory $\mathrm{T}$ cells by promoting their proliferation. Immunology (2006) 118(1):58-65. doi:10.1111/j.1365-2567.2006.02339.x

171. Tai P, Wang J, Jin H, Song X, Yan J, Kang Y, et al. Induction of regulatory $\mathrm{T}$ cells by physiological level estrogen. J Cell Physiol (2008) 214(2):456-64. doi:10.1002/jcp. 21221

172. Mao G, Wang J, Kang Y, Tai P, Wen J, Zou Q, et al. Progesterone increases systemic and local uterine proportions of CD4+CD25+ Treg cells during midterm pregnancy in mice. Endocrinology (2010) 151(11):5477-88. doi:10.1210/en. 2010-0426

173. Lin X-G, Zhou Q, Wang L, Gao Y, Zhang W-N, Luo Z-L, et al. Pregnancy estrogen drives the changes of T-lymphocyte subsets and cytokines and prolongs the survival of H-Y skin graft in murine model. Chin Med J (2010) 123(18):2593-9.

174. Valor L, Teijeiro R, Aristimuño C, Faure F, Alonso B, Andrés C, et al. Estradioldependent perforin expression by human regulatory T-cells. Eur J Clin Invest (2011) 41(4):357-64. doi:10.1111/j.1365-2362.2010.02414.x

175. Shirshev SV, Orlova EG, Zamorina SA, Nekrasova IV. Influence of reproductive hormones on the induction of CD4(+)CD25 (bright)Foxp (3+) regulatory T cells. Dokl Biol Sci (2011) 440:343-6. doi:10.1134/S0012496611050024

176. Xiong Y-H, Yuan Z, He L. Effects of estrogen on CD4(+) CD25(+) regulatory T cell in peripheral blood during pregnancy. Asian Pac J Trop Med (2013) 6(9):748-52. doi:10.1016/S1995-7645(13)60131-5

177. Thuere C, Zenclussen ML, Schumacher A, Langwisch S, Schulte-Wrede U, Teles $\mathrm{A}$, et al. Kinetics of regulatory $\mathrm{T}$ cells during murine pregnancy. Am J Reprod Immunol (2007) 58(6):514-23. doi:10.1111/j.1600-0897.2007.00538.x
178. Zhao J-X, Zeng Y-Y, Liu Y. Fetal alloantigen is responsible for the expansion of the CD4(+)CD25(+) regulatory $\mathrm{T}$ cell pool during pregnancy. J Reprod Immunol (2007) 75(2):71-81. doi:10.1016/j.jri.2007.06.052

179. Mjösberg J, Svensson J, Johansson E, Hellström L, Casas R, Jenmalm MC, et al. Systemic reduction of functionally suppressive CD4dimCD25highFoxp3+ Tregs in human second trimester pregnancy is induced by progesterone and 17beta-estradiol. J Immunol (2009) 183(1):759-69. doi:10.4049/jimmunol. 0803654

180. Mansour R, Tawab N, Kamal O, El-Faissal Y, Serour A, Aboulghar M, et al. Intrauterine injection of human chorionic gonadotropin before embryo transfer significantly improves the implantation and pregnancy rates in in vitro fertilization/intracytoplasmic sperm injection: a prospective randomized study. Fertil Steril (2011) 96(6):1370-4. doi:10.1016/j.fertnstert.2011.09.044

181. Chang X, Wu J. Effects of luteal estradiol pre-treatment on the outcome of IVF in poor ovarian responders. Gynecol Endocrinol (2013) 29(3):196-200. doi:10.3109/09513590.2012.736558

182. Davar R, Rahsepar M, Rahmani E. A comparative study of luteal estradiol pre-treatment in $\mathrm{GnRH}$ antagonist protocols and in micro dose flare protocols for poor-responding patients. Arch Gynecol Obstet (2013) 287(1):149-53. doi:10.1007/s00404-012-2522-0

183. Lukassen HGM, Joosten I, van Cranenbroek B, van Lierop MJC, Bulten J, Braat DDM, et al. Hormonal stimulation for IVF treatment positively affects the CD56bright/CD56dim NK cell ratio of the endometrium during the window of implantation. Mol Hum Reprod (2004) 10(7):513-20. doi:10.1093/molehr/gah067

184. Zhou J, Wang Z, Zhao X, Wang J, Sun H, Hu Y. An increase of Treg cells in the peripheral blood is associated with a better in vitro fertilization treatment outcome. Am J Reprod Immunol (2012) 68(2):100-6. doi:10.1111/j.1600-0897. 2012.01153.x

Conflict of Interest Statement: The authors declare that the research was conducted in the absence of any commercial or financial relationships that could be construed as a potential conflict of interest.

Received: 28 February 2014; accepted: 22 April 2014; published online: 08 May 2014. Citation: Schumacher A, Costa S-D and Zenclussen AC (2014) Endocrine factors modulating immune responses in pregnancy. Front. Immunol. 5:196. doi: 10.3389/fimmu.2014.00196

This article was submitted to Inflammation, a section of the journal Frontiers in Immunology.

Copyright $\odot 2014$ Schumacher, Costa and Zenclussen. This is an open-access article distributed under the terms of the Creative Commons Attribution License (CC BY). The use, distribution or reproduction in other forums is permitted, provided the original author(s) or licensor are credited and that the original publication in this journal is cited, in accordance with accepted academic practice. No use, distribution or reproduction is permitted which does not comply with these terms. 